\title{
CAN ECONOMIC POLICY UNCERTAINTY PREDICT EXCHANGE RATE AND ITS VOLATILITY? EVIDENCE FROM ASEAN COUNTRIES
}

\author{
Solikin M. Juhro ${ }^{1}$ and Dinh Hoang Bach Phan ${ }^{2}$ \\ ${ }^{1}$ Bank Indonesia Institute, Bank Indonesia, Jakarta, Indonesia. Email: solikin@bi.go.id \\ ${ }^{2}$ Taylor's Business School, Taylor's University, Malaysia. Email: dinhphan325@gmail.com
}

\begin{abstract}
This paper examines whether global Economic Policy Uncertainty (EPU) predicts exchange rates and their volatility in ten ASEAN countries using monthly data from January 1997 to December 2017. Applying the predictive regression model of Westerlund and Narayan $(2012,2015)$, we find that EPU positively and statistically significantly predicts the exchange rates of six out of ten currencies. A one standard deviation increase in the EPU index leads to a depreciation of between $0.050 \%$ and $2.047 \%$ in these currencies. Moreover, EPU predicts exchange rate volatility for all ten ASEAN countries. Their exchange rate volatilities increase by between $0.107 \%$ and $0.645 \%$ as a result of a one standard deviation increase in the EPU index. These results are robust to different forecasting horizons and subsample periods, and after controlling for the Global Financial Crisis.
\end{abstract}

Keywords: Economic policy uncertainty; Predictability; Exchange rate; ASEAN. JEL Classification: G12; G17.

Article history:

Received : July 1, 2018

Revised : October 22, 2018

Accepted : October 23, 2018

Available online : October 31, 2018

https://doi.org/10.21098/bemp.v21i2.974 


\section{INTRODUCTION}

We investigate whether global Economic Policy Uncertainty (EPU) can predict exchange rates and their volatility in ten ASEAN countries. The foreign exchange market is regarded as the most liquid and largest financial market (Record, 2003). Exchange rate stability is important for building and maintaining a robust economy. Increased exchange rate volatility, for instance, can have negative effects on an economy, including: (1) greater uncertainty on future consumption (Obstfeld and Rogoff, 1998; Devereux, 2004); (2) increased volatility of business profitability (Braun and Larrain, 2005; Aghion, Bacchetta, and Rancière, 2009); (3) increased risk for domestic and foreign direct investment (Campa, 1993; Darby, Hallett, Ireland, and Piscitelli, 1999; Urata and Kawai, 2000; Servén, 2003; Byrne and Davis, 2005); (4) increased inflation uncertainty and higher interest rates along with reduced investment and consumption (Grier and Grier, 2006); and (5) changes in production cost and increased international transaction risk (Baum and Caglayan, 2006). Given these issues, predicting exchange rate and its volatility are of direct interest to central bank policymaking. Therefore, understanding what predicts exchange rate and its volatility is important.

The literature on exchange rate prediction is rich and quite extensive. Various predictors have been examined, such as exchange rates themselves (Meese and Rogoff, 1983; Engel, Mark, and West, 2014), monetary fundamental variables (Giacomini and Rossi, 2010; Molodtsova, Nikolsko-Rzhevskyy, and Papell, 2011; and Rossi and Inoue, 2012), and commodity prices (Chen and Rogoff, 2003; Chen, Rogoff, and Rossi, 2010; and Ferraro, Rogoff, and Rossi 2015). The findings on predictability are mixed. We consider a relatively new predictor for predicting exchange rate and its volatility, the EPU index, which has become an important indicator of global economic performance. Several papers document the impact of EPU on forecasting macroeconomic and financial variables, including studies on predicting inflation (Colombo, 2013; Jones and Olson, 2013; Balcilar, Gupta, Jooste, 2017) recession (Karnizova and Li, 2014), GDP (Stockhammar and Osterholm, 2016), and stock returns (Phan, Sharma, and Tran, 2018).

However, the literature on using EPU to forecast exchange rate and its volatility is limited. ${ }^{3}$ Balcilar et al. (2016) test whether EPU predicts exchange rate in 16 countries and find no evidence of predictability, except the Brazilian Real. Dai, Zhang, Yu, and Li (2016) examine the Chinese market and find a causal relationship from EPU to the exchange rate in China when EPU is high. Krol (2014) finds that domestic and US EPU increase exchange rate volatility for a number of currencies. ${ }^{4}$ That EPU is a global index implies that it should affect both

\footnotetext{
3 The popular EPU index used in the literature was developed by Baker et al. (2016) and is found to be a good proxy to show the development of real-world economic policy uncertainty through time. This measure is highly correlated with other economic uncertainty and policy uncertainty measures (i.e., implied volatility of the stock market and Beige Book policy uncertainty from the Federal Reserve System). Baker et al. (2016) show that this measure significantly impacts financial and macro variables such as stock price volatility, investment, output, and employment.

4 Previous studies (Balcilar et al., 2016; Dai et al., 2016) explain the effect of EPU on exchange rate through two channels: (1) EPU as an additional risk factor in the market, and (2) an indirect channel via other macro variables.
} 
developing and emerging markets. Nevertheless, nothing is known about how the EPU performs in predicting exchange rate and its volatility in the ASEAN context. The present paper, therefore, addresses this research gap.

Our approach is as follows. First, we collect data for the ten ASEAN currencies and compute their return and volatility. For EPU index data, we use the Baker, Bloom, and Davis (2016) measure. Next, we employ the Feasible Generalized Least Squares (FGLS) model of Westerlund and Narayan (2012, 2015), which accounts for predictor persistency and endogeneity, and model heteroskedasticity to predict exchange rate and its volatility (using the EPU as a predictor). Finally, we test the robustness of our findings through forecasting horizons, subsamples of data, and controlling for the Global Financial Crisis (GFC).

Our empirical findings are threefold. First, we find that EPU predicts exchange rate for six out of ten ASEAN currencies. This result suggests that EPU can predict exchange rate but is country-dependent. The coefficients of EPU in the predictive regression models of these currencies are positive and statistically significant, implying that increased EPU leads to depreciation in these currencies. With a one standard deviation (equivalent to $40 \%$ of the monthly mean) increase in the EPU index, these six currencies depreciate by between $0.050 \%$ and $2.047 \%$ in the following month. Second, predictability is even stronger for volatility, as the coefficients of the EPU predictor are positive and statistically significant in the predictive regression models for all currencies. A one standard deviation increase in the EPU index leads to an increase in exchange rate volatility of between $0.107 \%$ and $0.645 \%$ in ten ASEAN country currencies. Finally, our conclusions pass robustness tests. Specifically, they remain the same when we use a longer forecasting horizon, different subsamples of data, and controlling for the GFC.

This paper proceeds as follows. We describe our data sample and predictive regression model in Section II. Next, Section III discusses our main findings and robustness test results. Finally, our conclusions are set forth in Section IV.

\section{DATA AND METHODOLOGY}

\section{A. Data}

Our dataset consists of exchange rate series of ten ASEAN countries vis-à-vis the US dollar (USD). ${ }^{5}$ The rates are direct quotes (domestic currency per USD) such that an increase represents depreciation of the domestic currency vis-à-vis the USD. We calculate monthly log returns for exchange rates, and their monthly volatilities are calculated as $\sigma_{t}=\sqrt{\frac{1}{N-1} \sum_{t=1}^{N}\left(r_{t}-E\left(r_{t}\right)\right)^{2}} \times \sqrt{N}$, where $r_{t}$ is daily exchange rate return.

\footnotetext{
5 Brunei Dollar (BND), Cambodian Riel (KHR), Indonesian Rupiah (IDR), Lao Kip (LAK), Malaysian Ringgit (MYR), Myanmar Kyat (MMK), Philippine Peso (PHP), Singapore Dollar (SGD), Thai Baht (THB), and Vietnam Dong (VND).
} 
The second dataset is EPU. Following previous studies (Wang, Chen, and Huang, 2014; Ajmi, Aye, Balcilar, El Montasser, and Gupta, 2015; Li, Balcilar, Gupta, and Chang, 2016; Li and Peng, 2017; Phan, Sharma, and Tran, 2018), we use the Baker et al. (2016) EPU measure. Greater uncertainty manifests as a higher value of the index. EPU data are available on Baker's website. ${ }^{6}$ Our sample period and data frequency are chosen based on EPU data availability. We use monthly data from January 1997 to December 2017, comprising 252 observations. Figure I plots EPU and exchange rates of ten ASEAN countries.

\section{Figure 1. Plots of Economic Policy Uncertainty and Exchange Rates}

This figure plots the Economic Policy Uncertainty (EPU) and exchange rates of 10 ASEAN countries. These countries are: Brunei Dollar (BND), Cambodian Riel (KHR), Indonesian Rupiah (IDR), Lao Kip (LAK), Malaysian Ringgit (MYR), Myanmar Kyat (MMK), Philippine Peso (PHP), Singapore Dollar (SGD), Thai Baht (THB), and Vietnam Dong (VND). The data are time-series covering the period January 1997-December 2017.
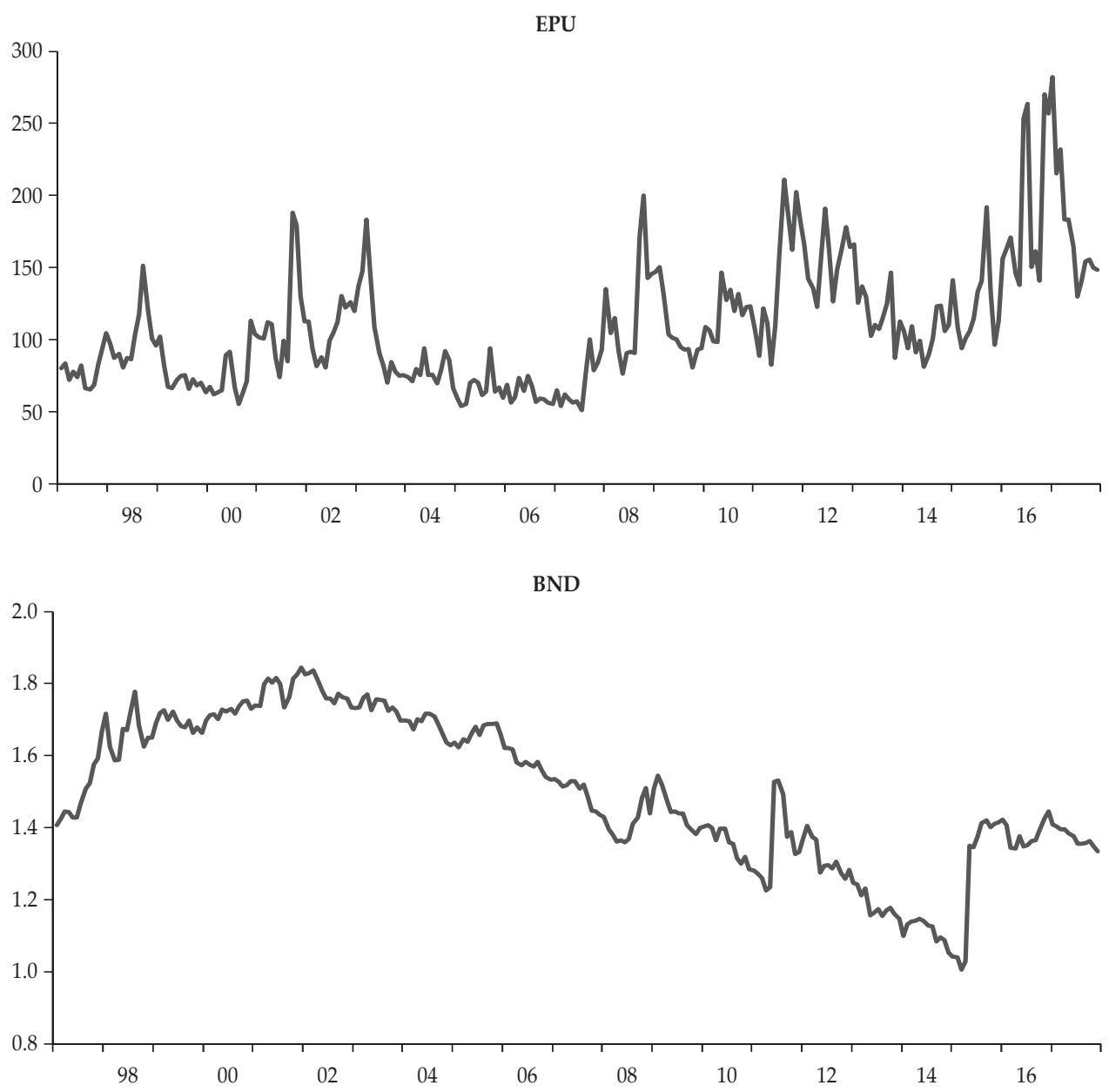

6 http://www.policyuncertainty.com 
Figure 1. Plots of Economic Policy Uncertainty and Exchange Rates (Continued)

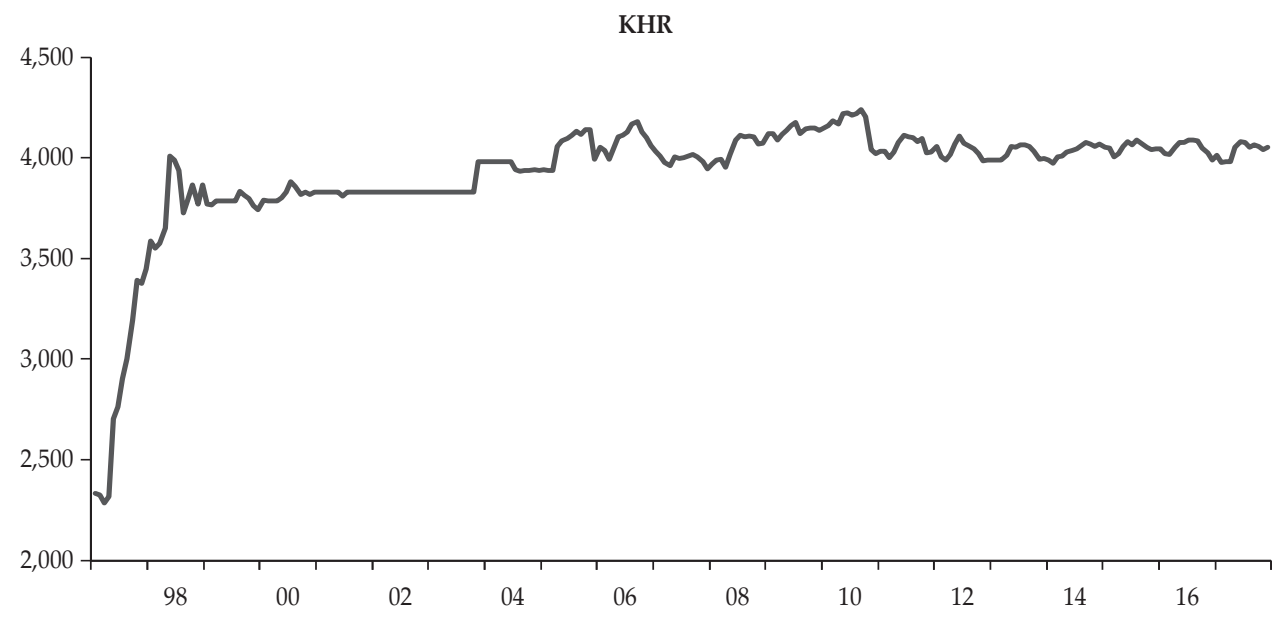

IDR

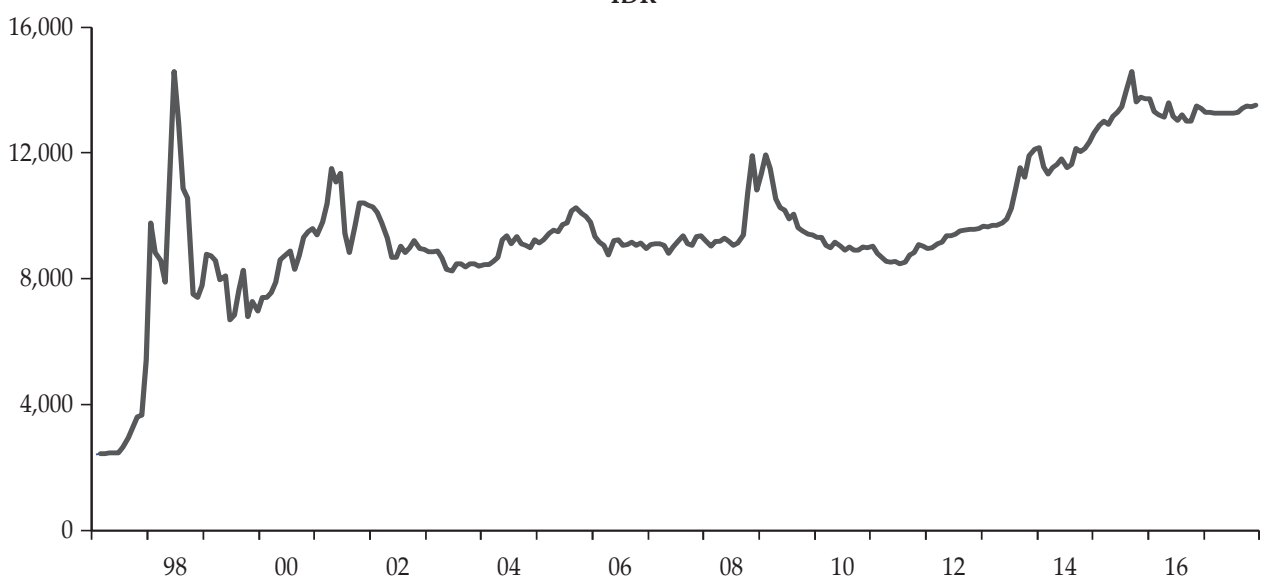

LAK

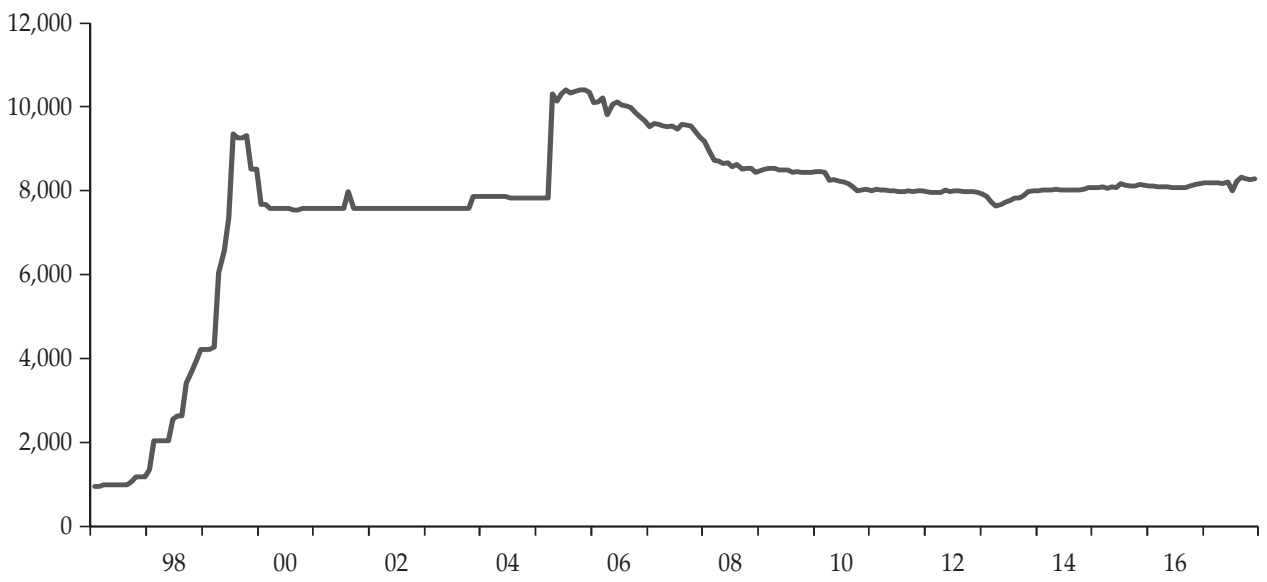


Figure 1. Plots of Economic Policy Uncertainty and Exchange Rates (Continued)
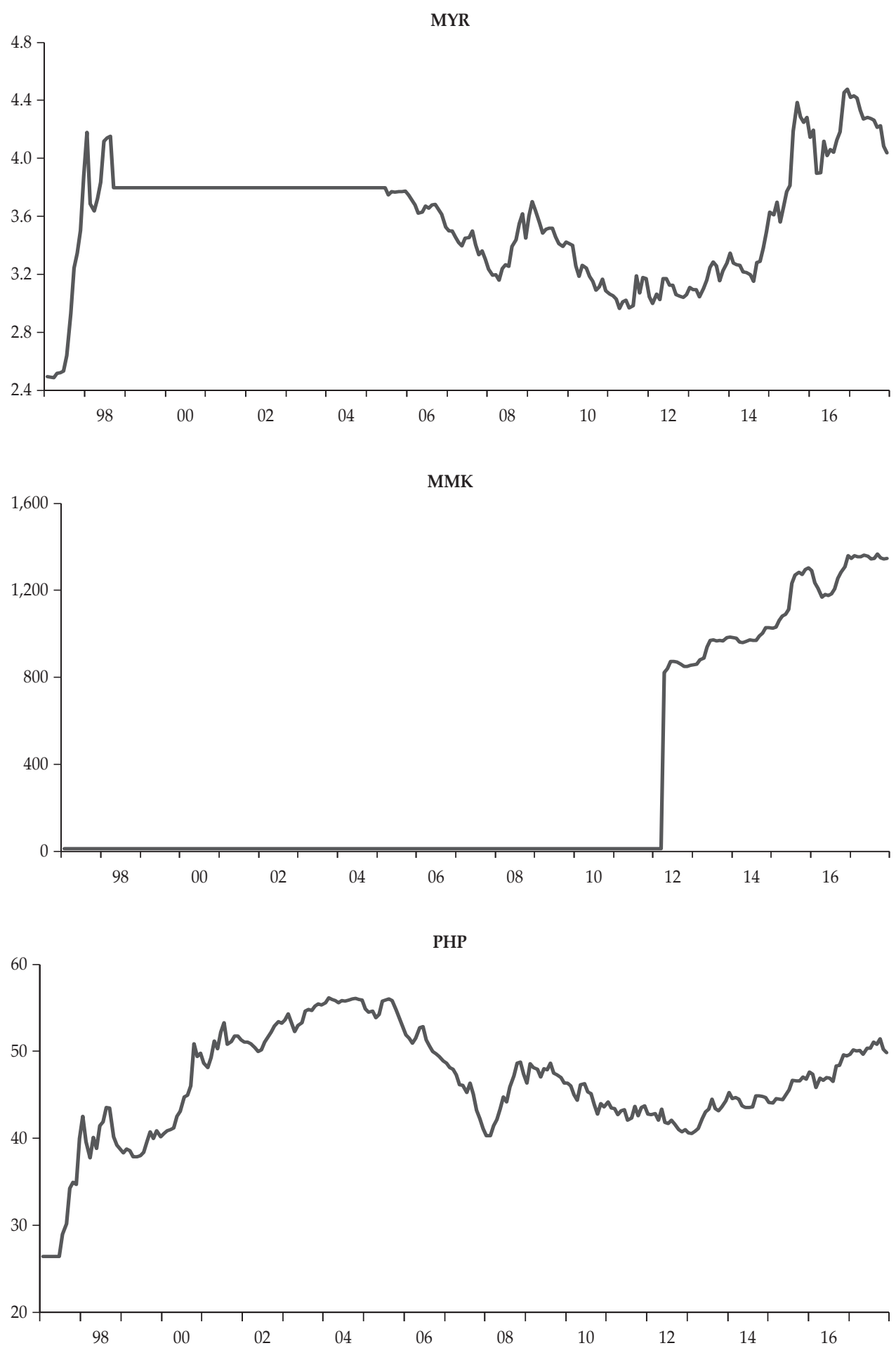
Figure 1. Plots of Economic Policy Uncertainty and Exchange Rates (Continued)
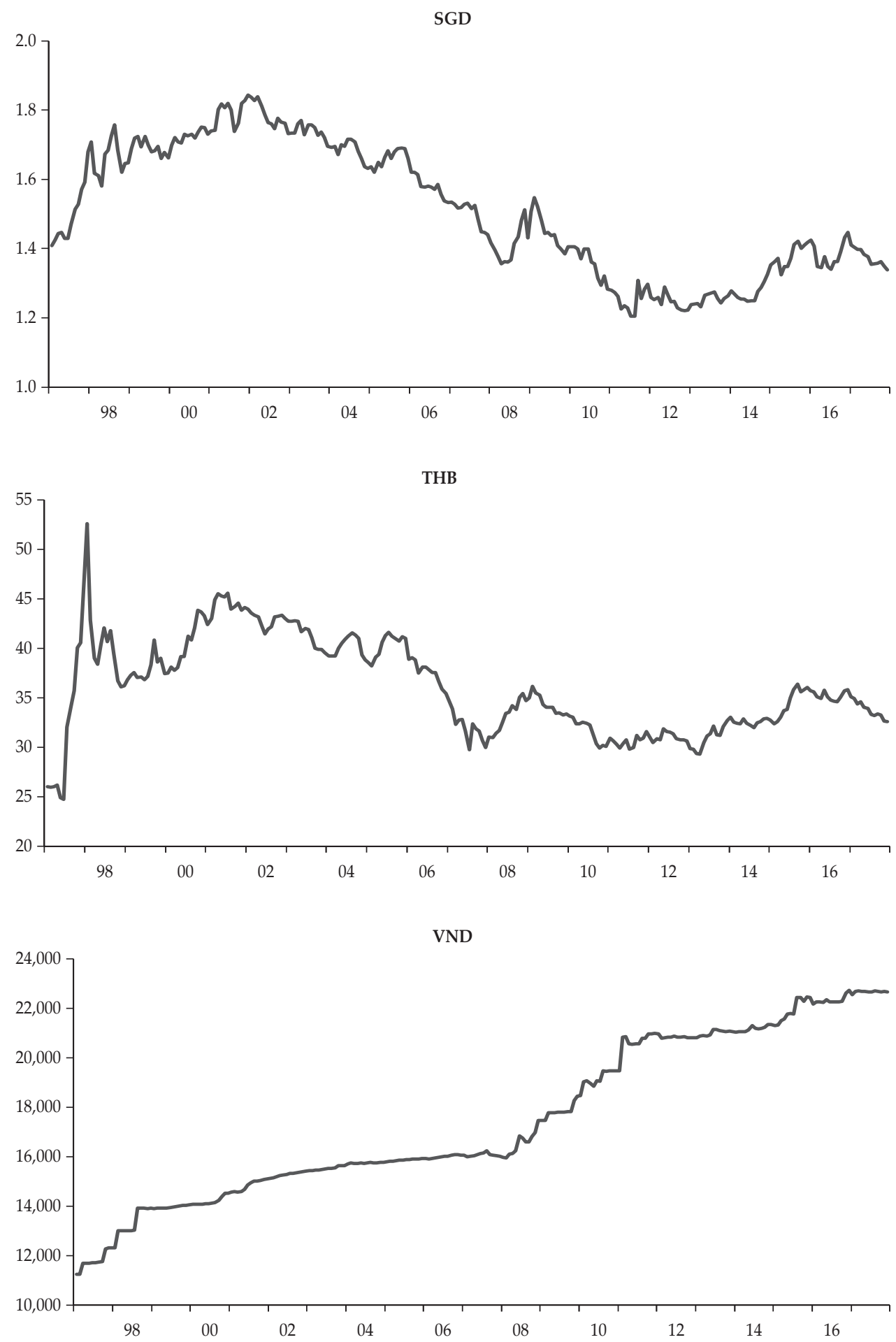
B. Methodology

Following the predictability literature, the predictive regression model can be written as:

$$
y_{t}=\alpha+\beta x_{t-1}+\epsilon_{t}
$$

where $x_{t}$ is exchange rate return or its volatility in month $t$ for one of ten ASEAN countries, and the predictor $x_{t-1}$ is EPU. This model has a number of drawbacks due to potential persistency, endogeneity, and heteroskedasticity, as pointed out in Stambaugh (1999) and Lewellen (2004). Consider that EPU follows an autoregressive model as follows:

$$
\begin{aligned}
& x_{t}=\mu(1-\rho)+\rho x_{t-1}+\varepsilon_{t} \\
& \epsilon_{t}=\gamma \varepsilon_{t}+\eta_{t}
\end{aligned}
$$

where $|\rho| \leq 1$. $\epsilon_{t}$ and $\varepsilon_{t}$ are expected to be uncorrelated and have mean zero. If this assumption is violated, the predictor is endogenous and leads to a biased $\beta$ using OLS estimation. The predictor EPU can also be highly persistent. A bias-adjusted estimator is introduced by Lewellen (2004); it eliminates bias due to persistency and endogeneity, but the efficiency problem inherent from heteroskedasticity remains in that model. WN $(2012,2015)$ propose the FGLS estimator, which accounts for all three potential issues. This model is used widely in the prediction literature on stock returns (see Bannigidadmath and Narayan, 2015; Narayan and Bannigidadmath, 2015; Narayan and Gupta, 2015; Narayan, Sharma, and Thuraisamy, 2015; Phan, Sharma, and Narayan, 2015; Narayan, Phan, Thuraisamy, and Westerlund, 2016; Devpura, Sharma, and Narayan, 2017; Narayan, Phan, Narayan, and Bannigidadmath, 2017; Narayan, Phan, and Sharma, 2017), commodities (Sharma, 2016; Han, Lv, and Yin, 2017), inflation (Salisu and Isah, 2018), economic growth (Narayan, Sharma, Poon,, Westerlund, 2014), and carbon emissions (Narayan and Sharma, 2015).

\section{EMPIRICAL FINDINGS}

\section{A. Preliminary Results}

Table 1 reports common descriptive statistics of exchange rate return and its volatility for ten ASEAN countries (Panels A \& B) and the predictor, EPU, (Panel C). Considering the exchange rate returns in Panel A, we note that the monthly average in the first column varies from $-0.019 \%$ in the case of the Brunei dollar to $2.156 \%$ for the Myanmar Kyat. In our sample period, the BND and SGD appreciate while the other eight currencies depreciate against the USD. The second to last column reports the autoregressive coefficient of order 1 . The coefficients are less than $25 \%$ in all cases, which suggests that persistence is low. In the last column, we find strong evidence for ARCH effects from the results reported. The "no ARCH" null hypothesis is rejected for five currencies, IDR, MYR, PHP, SGD, and THB. 
Table 1.

\section{Descriptive Statistic}

This table reports selective descriptive statistics for exchange rate returns (Panel A), exchange rate return volatility (Panel B) and the predictor, EPU (Panel C). The statistics include the mean value, standard deviation (SD), AR(1), and ARCH(1). AR(1) refers to the autoregressive coefficient of order 1, while ARCH (1) refers to a Lagrange multiplier test of the zero slope restriction in an $\mathrm{ARCH}$ regression of order 1 and the $p$-value of the test is reported. The JB test is the Jarque-Bera test that examines the normality of the data series.

\begin{tabular}{|c|c|c|c|c|c|c|c|}
\hline \multicolumn{8}{|c|}{ Panel A: Exchange Rate Returns } \\
\hline & Mean & SD & Skewness & Kurtosis & JB & $\mathrm{AR}(1)$ & $\mathrm{ARCH}$ \\
\hline Brunei Dollar (BND) & -0.019 & 2.922 & 4.622 & 43.618 & 0.000 & 0.049 & 0.840 \\
\hline Cambodian Riel (KHR) & 0.226 & 1.616 & 4.370 & 39.099 & 0.000 & 0.215 & 0.574 \\
\hline Indonesian Rupiah (IDR) & 0.693 & 7.135 & 2.760 & 28.584 & 0.000 & 0.227 & 0.000 \\
\hline Lao Kip (LAK) & 0.873 & 5.118 & 5.262 & 35.290 & 0.000 & 0.221 & 0.402 \\
\hline Malaysian Ringgit (MYR) & 0.187 & 2.454 & 0.543 & 10.186 & 0.000 & 0.190 & 0.000 \\
\hline Myanmar Kyat (MMK) & 2.156 & 30.597 & 15.734 & 249.035 & 0.000 & 0.000 & 0.949 \\
\hline Philippine Peso (PHP) & 0.255 & 2.453 & 1.578 & 10.857 & 0.000 & 0.109 & 0.035 \\
\hline Singapore Dollar (SGD) & -0.018 & 1.773 & 0.387 & 5.428 & 0.000 & 0.001 & 0.011 \\
\hline Thai Baht (THB) & 0.095 & 3.329 & 1.487 & 24.328 & 0.000 & 0.158 & 0.002 \\
\hline Vietnam Dong (VND) & 0.284 & 0.945 & 4.280 & 25.562 & 0.000 & -0.020 & 0.611 \\
\hline \multicolumn{8}{|c|}{ Panel B: Exchange Rate Return Volatility } \\
\hline & Mean & SD & Skewness & Kurtosis & JB & $\mathrm{AR}(1)$ & $\mathrm{ARCH}$ \\
\hline Brunei Dollar (BND) & 2.799 & 5.123 & 4.387 & 22.255 & 0.000 & 0.637 & 0.000 \\
\hline Cambodian Riel (KHR) & 1.677 & 3.728 & 7.443 & 68.681 & 0.000 & 0.179 & 0.991 \\
\hline Indonesian Rupiah (IDR) & 3.595 & 5.619 & 5.243 & 40.213 & 0.000 & 0.793 & 0.000 \\
\hline Lao Kip (LAK) & 1.676 & 4.960 & 5.076 & 32.076 & 0.000 & 0.241 & 0.390 \\
\hline Malaysian Ringgit (MYR) & 1.510 & 2.003 & 3.536 & 21.199 & 0.000 & 0.822 & 0.000 \\
\hline Myanmar Kyat (MMK) & 4.755 & 43.066 & 11.076 & 123.781 & 0.000 & 0.495 & 0.000 \\
\hline Philippine Peso (PHP) & 1.943 & 1.744 & 4.184 & 27.833 & 0.000 & 0.504 & 0.045 \\
\hline Singapore Dollar (SGD) & 1.551 & 0.840 & 2.696 & 14.580 & 0.000 & 0.701 & 0.000 \\
\hline Thai Baht (THB) & 2.092 & 2.509 & 3.797 & 19.339 & 0.000 & 0.655 & 0.000 \\
\hline Vietnam Dong (VND) & 0.617 & 1.431 & 5.786 & 43.961 & 0.000 & 0.447 & 0.000 \\
\hline \multicolumn{8}{|c|}{ Panel C: Predictor } \\
\hline & Mean & SD & Skewness & Kurtosis & $\mathrm{JB}$ & $\mathrm{AR}(1)$ & $\mathrm{ARCH}$ \\
\hline EPU & 109.082 & 43.617 & 1.304 & 5.057 & 0.000 & 0.839 & 0.000 \\
\hline
\end{tabular}

We now examine the exchange rate volatilities of ASEAN countries in Panel B. The results suggest that MMK has the highest volatility (mean value, $4.755 \%$ ) while VND has the lowest volatility (mean value, 0.617\%). Five currencies (BND, IDR, MYR, SGD, and THB) have first-order autoregressive coefficients greater than $60 \%$, which implies strong persistency in exchange rate volatility in these countries. In addition, ARCH effects are found in eight out of ten currencies (except KHR and LAK). Considering the predictor EPU in Panel C, we also find strong evidence for persistency and heteroskedasticity.

We test for endogeneity for the predictor EPU and report the results in Table 2. We examine the coefficient $\gamma$ in Equation (3), which is a regression of residuals from Equation (1) on residuals from the AR(1) predictor regression model Equation (2). We observe limited evidence for endogeneity, as the coefficient $\gamma$ is statistically insignificant in all cases (except the predictive regression model of SGD volatility). 
Table 2.

\section{Endogeneity Test}

This table reports the results for the endogeneity test in the predictive regression model. The endogeneity test is based on a regression of residuals from the predictive regression model on residuals from the first-order autoregressive predictor regression model. The equation is as $\epsilon_{t}=\gamma \varepsilon_{t}+\eta_{t^{\prime}}$ where $\epsilon_{t}$ is the residual from the predictive regression model $y_{t}=\alpha+\beta x_{t-1}+\epsilon_{t}$ and $\varepsilon_{t}$ is the residual from the AR(1) regression of the predictor $x_{t}=\mu(1-\rho)+\rho x_{t-1}+\varepsilon_{-}$t. We report the $p$-value of the test that the coefficient $\gamma$ in the equation is zero. Rejecting the null that $\gamma=0$ suggests the endogeneity exists in the predictive regression model. Finally, ${ }^{* *}$ denotes the statistical significance at the $5 \%$ level.

\begin{tabular}{lcccc}
\hline & \multicolumn{2}{c}{ Exchange Rate Returns } & \multicolumn{2}{c}{ Exchange Rate Return Volatility } \\
\hline & $\gamma$ & $p$-value & $\gamma$ & $p$-value \\
\hline Brunei Dollar (BND) & 0.006 & 0.421 & 0.010 & 0.483 \\
Cambodian Riel (KHR) & -0.002 & 0.723 & -0.009 & 0.359 \\
Indonesian Rupiah (IDR) & 0.020 & 0.296 & -0.011 & 0.469 \\
Lao Kip (LAK) & -0.006 & 0.637 & -0.004 & 0.780 \\
Malaysian Ringgit (MYR) & 0.008 & 0.205 & 0.007 & 0.188 \\
Myanmar Kyat (MMK) & -0.030 & 0.709 & 0.102 & 0.376 \\
Philippine Peso (PHP) & 0.008 & 0.242 & 0.002 & 0.636 \\
Singapore Dollar (SGD) & 0.005 & 0.314 & $0.005^{* *}$ & 0.018 \\
Thai Baht (THB) & 0.004 & 0.673 & -0.005 & 0.451 \\
Vietnam Dong (VND) & 0.000 & 0.894 & -0.001 & 0.755 \\
\hline
\end{tabular}

In summary, the preliminary results suggest strong evidence for persistency and heteroskedasticity, and weak evidence for endogeneity. Therefore, it is rational to use the FGLS estimator of WN $(2012,2015)$ to eliminate biases and inefficiency.

\section{B. Baseline Results}

We report the results for the prediction test in Table 3. The coefficient (columns 2 and 4) and the $t$-stat for the null hypothesis of "no predictability" for the EPU predictor (columns 3 and 5) are reported. Considering the exchange rate, evidence of predictability is found in six currencies: KHR, IDR, LAK, MYR, MMK, and PHP. The coefficients of EPU are positive and statistically significant, implying that an increase in EPU indicates depreciation in these currencies. For every point of EPU index increase, these currencies depreciate by between $0.001 \%$ (MYR) and $0.047 \%$ (MMK). A one standard deviation increase in the EPU index leads these currencies to depreciate by $0.050 \%$ to $2.047 \%$ in the next month. This result indicates that exchange rate predictability using EPU is country-dependent. 
Table 3.

\section{Exchange Rate and Its Volatility Predictability}

This table reports results on the predictability of exchange rate and its volatility, where the predictor is EPU. The predictive regression model is the bias-adjusted FGLS estimator proposed by Westerlund and Narayan (2012, 2015). The coefficient of the EPU predictor and the $p$-value associated with the null hypothesis of "no predictability" are reported. Finally, ${ }^{*},{ }^{* *}$, and ${ }^{* * *}$ denote significance at the $10 \%, 5 \%$ and $1 \%$ levels, respectively.

\begin{tabular}{lcccc}
\hline & \multicolumn{2}{c}{ Exchange Rate Returns } & \multicolumn{2}{c}{ Exchange Rate Return Volatility } \\
\hline & Coefficient & $p$-value & Coefficient & $p$-value \\
\hline Brunei Dollar (BND) & -0.004 & 0.224 & $0.011^{* * *}$ & 0.000 \\
Cambodian Riel (KHR) & $0.003^{* * *}$ & 0.009 & $0.008^{* * *}$ & 0.000 \\
Indonesian Rupiah (IDR) & $0.010^{* * *}$ & 0.000 & $0.015^{* * *}$ & 0.000 \\
Lao Kip (LAK) & $0.007^{* * *}$ & 0.000 & $0.009^{* * *}$ & 0.000 \\
Malaysian Ringgit (MYR) & $0.001^{* *}$ & 0.012 & $0.012^{* * *}$ & 0.000 \\
Myanmar Kyat (MMK) & $0.047^{* * *}$ & 0.000 & $0.008^{* * *}$ & 0.000 \\
Philippine Peso (PHP) & $0.005^{*}$ & 0.071 & $0.011^{* * *}$ & 0.000 \\
Singapore Dollar (SGD) & 0.003 & 0.198 & $0.013^{* * *}$ & 0.000 \\
Thai Baht (THB) & -0.002 & 0.465 & $0.010^{* * *}$ & 0.000 \\
Vietnam Dong (VND) & 0.001 & 0.259 & $0.002^{* * *}$ & 0.000 \\
\hline
\end{tabular}

We also observe that an EPU increase leads to an increase in the volatility of all ASEAN country currencies. The coefficients of EPU in the exchange rate volatility predictive regression models are statistically significantly positive in all currencies. The most affected currency is the IDR and the least affected currency is the VND. A one index point increase in the EPU index leads to an increase of $0.015 \%$ in IDR volatility and $0.002 \%$ in VND volatility. If we consider a one standard deviation increase in the EPU index, the increases are $0.107 \%$ and $0.645 \%$, respectively.

\section{Robustness Tests}

We utilize three robustness test analyses for our baseline results. First, we consider predictability at longer forecasting horizons. We use EPU to predict exchange rate and its volatility two months and three months ahead. The results are reported in Table 4. When we consider a two-month forecasting horizon (Panel A), our findings are in line with the results from the one-month forecasting horizon. EPU is able to predict exchange rate two months ahead for five currencies: KHR, IDR, LAK, MMK, and PHP. A one standard deviation increase in the EPU index leads to depreciation of between $0.116 \%$ and $2.752 \%$ in these currencies. Once again, the coefficients of EPU in the exchange rate volatility predictive regression models are statistically significantly positive for all currencies. The coefficients vary within a range of 0.002 (LAK and MYR) to 0.022 (MMK). We observe similar results using the three-month forecasting horizon. One noteworthy feature is that the predictive power of EPU on exchange rate declines with increased forecasting horizon. That is, the number of significant predictive results is six currencies in the case of the one-month forecasting horizon, and five and four currencies for the two-month and three-month forecasting horizons, respectively. 
Table 4.

Robustness Test Using Different Forecasting Horizons

This table reports results on two-months (Panel A) and three-months (Panel B) ahead predictability of the exchange rate return and its volatility using EPU as the predictor. The predictive regression model is the bias-adjusted FGLS estimator proposed by Westerlund and Narayan $(2012,2015)$. The coefficient of the EPU predictor and the $p$-value associated with the null hypothesis of "no predictability" are reported. Finally, ${ }^{*}, * *$, and *** denote significance at the $10 \%, 5 \%$ and $1 \%$ levels, respectively.

\begin{tabular}{lcccc}
\hline \multicolumn{5}{c}{ Panel A: Two-Month Forecasting Horizon } \\
\hline & Exchange Rate Returns & Exchange Rate Return Volatility \\
\hline & Coefficient & $p$-value & Coefficient & $p$-value \\
\hline Brunei Dollar (BND) & 0.000 & 0.852 & $0.019^{* * *}$ & 0.000 \\
Cambodian Riel (KHR) & $0.003^{* * *}$ & 0.001 & $0.008^{* * *}$ & 0.000 \\
Indonesian Rupiah (IDR) & $0.010^{* * *}$ & 0.000 & $0.013^{* * *}$ & 0.000 \\
Lao Kip (LAK) & $0.015^{* * *}$ & 0.000 & $0.002^{* * *}$ & 0.000 \\
Malaysian Ringgit (MYR) & -0.001 & 0.246 & $0.002^{* * *}$ & 0.000 \\
Myanmar Kyat (MMK) & $0.063^{*}$ & 0.075 & $0.022^{* * *}$ & 0.000 \\
Philippine Peso (PHP) & $0.005^{* *}$ & 0.021 & $0.011^{* * *}$ & 0.000 \\
Singapore Dollar (SGD) & 0.001 & 0.719 & $0.013^{* * *}$ & 0.000 \\
Thai Baht (THB) & -0.004 & 0.198 & $0.009^{* * *}$ & 0.000 \\
Vietnam Dong (VND) & 0.002 & 0.153 & $0.003^{* * *}$ & 0.000 \\
\hline
\end{tabular}

\begin{tabular}{|c|c|c|c|c|}
\hline \multicolumn{5}{|c|}{ Panel B: Three-Month Forecasting Horizon } \\
\hline & \multicolumn{2}{|c|}{ Exchange Rate Returns } & \multicolumn{2}{|c|}{ Exchange Rate Return Volatility } \\
\hline & Coefficient & $p$-value & Coefficient & $p$-value \\
\hline Brunei Dollar (BND) & 0.002 & 0.519 & $0.010^{* * *}$ & 0.000 \\
\hline Cambodian Riel (KHR) & 0.000 & 0.842 & $0.008^{* * *}$ & 0.000 \\
\hline Indonesian Rupiah (IDR) & $0.009^{* * *}$ & 0.000 & $0.016^{* * *}$ & 0.000 \\
\hline Lao Kip (LAK) & $0.010^{* * *}$ & 0.000 & $0.009^{* * *}$ & 0.000 \\
\hline Malaysian Ringgit (MYR) & 0.001 & 0.217 & $0.002^{* * *}$ & 0.000 \\
\hline Myanmar Kyat (MMK) & $0.040^{* * *}$ & 0.000 & $0.010^{* * *}$ & 0.000 \\
\hline Philippine Peso (PHP) & $0.005^{*}$ & 0.051 & $0.011^{* * *}$ & 0.000 \\
\hline Singapore Dollar (SGD) & 0.001 & 0.667 & $0.013^{* * *}$ & 0.000 \\
\hline Thai Baht (THB) & -0.002 & 0.513 & $0.010^{* * *}$ & 0.000 \\
\hline Vietnam Dong (VND) & 0.002 & 0.192 & $0.003^{* * *}$ & 0.000 \\
\hline
\end{tabular}

Our second robustness test uses subsample periods. Our sample is monthly data over 21 years, which is sufficient for this robustness test. We divide our sample into two subsample periods: January 1997-December 2006 and January 2007December 2017. We re-estimate our predictive regression models for exchange rate and its volatility in ten ASEAN countries and report the results in Table 5. EPU positively and statistically significantly predicts the exchange rate returns of five currencies in the first subsample period 1997-2006 (KHR, LAK, MYR, MMK, and PHP), and in the second subsample period 2007-2017 (IDR, MYR, MMK, PHP, and VND). In addition, EPU predicts exchange rate volatility for all currencies regardless of subsample period. 
Table 5.

\section{Robustness Test Using Sub-Sample Periods}

This table reports results on the predictability of exchange rate returns and its volatility using EPU as the predictor for two subsample periods. The predictive regression model is the bias-adjusted FGLS estimator proposed by Westerlund and Narayan (2012, 2015). The coefficient of the EPU predictor and the $p$-value associated with the null hypothesis of "no predictability" are reported. Finally, ${ }^{*}, * *$, and ${ }^{* * *}$ denote significance at the $10 \%, 5 \%$ and $1 \%$ levels, respectively.

\begin{tabular}{|c|c|c|c|c|}
\hline \multicolumn{5}{|c|}{ Panel A: Sub-Sample Period 1997-2006 } \\
\hline & \multicolumn{2}{|c|}{ Exchange Rate Returns } & \multicolumn{2}{|c|}{ Exchange Rate Return Volatility } \\
\hline & Coefficient & $p$-value & Coefficient & $p$-value \\
\hline Brunei Dollar (BND) & 0.003 & 0.259 & $0.014^{* * *}$ & 0.000 \\
\hline Cambodian Riel (KHR) & $0.009^{* * *}$ & 0.000 & $0.008^{* * *}$ & 0.000 \\
\hline Indonesian Rupiah (IDR) & -0.007 & 0.623 & $0.031^{* * *}$ & 0.000 \\
\hline Lao Kip (LAK) & $0.024^{* * *}$ & 0.000 & $0.005^{* * *}$ & 0.005 \\
\hline Malaysian Ringgit (MYR) & $0.001^{* * *}$ & 0.000 & $0.000^{* * *}$ & 0.000 \\
\hline Myanmar Kyat (MMK) & $0.000^{* *}$ & 0.033 & $0.014^{* * *}$ & 0.000 \\
\hline Philippine Peso (PHP) & $0.019^{* * *}$ & 0.000 & $0.016^{* * *}$ & 0.000 \\
\hline Singapore Dollar (SGD) & 0.004 & 0.236 & $0.014^{* * *}$ & 0.000 \\
\hline Thai Baht (THB) & 0.006 & 0.223 & $0.016^{* * *}$ & 0.000 \\
\hline Vietnam Dong (VND) & $-0.003^{* * *}$ & 0.000 & $0.001^{* * *}$ & 0.000 \\
\hline \multicolumn{5}{|c|}{ Panel B: Sub-Sample Period 2007-2017 } \\
\hline & \multicolumn{2}{|c|}{ Exchange Rate Returns } & \multicolumn{2}{|c|}{ Exchange Rate Return Volatility } \\
\hline & Coefficient & $p$-value & Coefficient & $p$-value \\
\hline Brunei Dollar (BND) & -0.001 & 0.847 & $0.014^{* * *}$ & 0.000 \\
\hline Cambodian Riel (KHR) & -0.002 & 0.204 & $0.008^{* * *}$ & 0.000 \\
\hline Indonesian Rupiah (IDR) & $0.007^{* *}$ & 0.018 & $0.007^{* * *}$ & 0.000 \\
\hline Lao Kip (LAK) & -0.001 & 0.469 & $0.002^{* * *}$ & 0.000 \\
\hline Malaysian Ringgit (MYR) & $0.010^{* * *}$ & 0.001 & $0.014^{* * *}$ & 0.000 \\
\hline Myanmar Kyat (MMK) & $0.034^{* * *}$ & 0.000 & $0.031^{* * *}$ & 0.000 \\
\hline Philippine Peso (PHP) & $0.005^{*}$ & 0.073 & $0.010^{* * *}$ & 0.000 \\
\hline Singapore Dollar (SGD) & -0.001 & 0.753 & $0.013^{* * *}$ & 0.000 \\
\hline Thai Baht (THB) & $-0.006^{* * *}$ & 0.007 & $0.008^{* * *}$ & 0.000 \\
\hline Vietnam Dong (VND) & $0.003^{* * *}$ & 0.000 & $0.003^{* * *}$ & 0.000 \\
\hline
\end{tabular}

Our final robustness test controls for the GFC. ${ }^{7}$ We add a dummy variable that equals 1 during the GFC period July 2007-December 2009, and zero otherwise, to our predictive regression models. The results are reported in Table 6 . We find similar results with our baseline regression models.

\footnotetext{
7 We also have a robustness test that controls for the ASIAN Financial Crisis and we find robust results. The results are available up on request.
} 
Table 6.

\section{Robustness Test Controlling for the Global Financial Crisis}

This table reports results on the predictability of exchange rate returns and its volatility using EPU as the predictor after controlling for the global financial crisis effect. The predictive regression model is the bias-adjusted FGLS estimator proposed by Westerlund and Narayan $(2012,2015)$. The coefficient of the EPU predictor and the $p$-value associated with the null hypothesis of "no predictability" are reported. Finally, ${ }^{*}, * *$, and ${ }^{* * *}$ denote significance at the $10 \%, 5 \%$ and $1 \%$ levels, respectively.

\begin{tabular}{lcccc}
\hline & \multicolumn{2}{c}{ Exchange Rate Returns } & \multicolumn{2}{c}{ Exchange Rate Return Volatility } \\
\hline & Coefficient & $p$-value & Coefficient & $p$-value \\
\hline Brunei Dollar (BND) & -0.004 & 0.174 & $0.014^{* * * *}$ & 0.000 \\
Cambodian Riel (KHR) & -0.001 & 0.538 & $0.008^{* * *}$ & 0.000 \\
Indonesian Rupiah (IDR) & $0.005^{*}$ & 0.097 & $0.023^{* * *}$ & 0.000 \\
Lao Kip (LAK) & $0.007^{* * *}$ & 0.000 & $0.011^{*}$ & 0.089 \\
Malaysian Ringgit (MYR) & $0.001^{* * *}$ & 0.001 & $0.000^{* * *}$ & 0.000 \\
Myanmar Kyat (MMK) & 0.024 & 0.793 & $0.003^{* * *}$ & 0.000 \\
Philippine Peso (PHP) & $0.004^{*}$ & 0.090 & $0.015^{* * *}$ & 0.000 \\
Singapore Dollar (SGD) & 0.003 & 0.251 & $0.015^{* * *}$ & 0.000 \\
Thai Baht (THB) & -0.002 & 0.435 & $0.016^{* * *}$ & 0.000 \\
Vietnam Dong (VND) & $-0.003^{* * *}$ & 0.001 & $0.001^{* * * *}$ & 0.000 \\
\hline
\end{tabular}

\section{CONCLUSION}

This paper investigates whether EPU can predict ASEAN exchange rates and their volatilities. Our analysis is based on monthly data over the period January 1997 to December 2017 for ten ASEAN countries. We apply the FGLS model of Westerlund and Narayan (2012, 2015), which accounts for persistency, endogeneity, and heteroskedasticity issues.

Our results suggest strong evidence for the predictability of exchange rates and their volatility using EPU as the predictor. Our baseline findings show that EPU positively and statistically significantly predicts the exchange rate of six out of ten currencies in our sample: KHR, IDR, LAK, MYR, MMK, and PHP. Exchange rate predictability is country-dependent. An increase in the EPU index (of one standard deviation) leads to a depreciation of $0.050 \%$ to $2.047 \%$ for these currencies in the next month. In terms of exchange rate volatility, the predictive results are statistically significantly positive in all cases. An increase in EPU (of one standard deviation) leads to an increase in exchange rate volatility (from $0.107 \%$ to $0.645 \%$ ) in all ASEAN country currencies.

We test the consistency of our baseline empirical analysis via two robustness tests. First, we use EPU to predict exchange rate and its volatility for two months and three months ahead. Second, we split our sample into two subsample periods: January 1997-December 2006 and January 2007-December 2017. Finally, we control for the GFC. We observe that our conclusions pass these robustness tests. 


\section{REFERENCES}

Aghion, P., Bacchetta, P., \& Rancière, R. (2006). Exchange rate volatility and productivity growth: The role of financial development. Journal of Monetary Economics, 56, 494-513.

Ajmi, A., Aye, G., Balcilar, M., El Montasser, G., \& Gupta, R. (2015). Causality between US economic policy and equity market uncertainties: Evidence from linear and nonlinear tests. Journal of Applied Economics, 18, 225-246.

Baker, S. R., Bloom, N., \& Davis, S.J. (2016). Measuring economic policy uncertainty. The Quarterly Journal of Economics, 131, 1593-1636.

Balcilar, M., Gupta, R., \& Kyei, C. (2016). Does economic policy uncertainty predict exchange rate returns and volatility? Evidence from a nonparametric causalityin-quantiles test. Open Economies Review, 27, 229-250.

Balcilar, M., Gupta, R., \& Jooste, C. (2017). Long memory, economic policy uncertainty and forecasting US inflation: a Bayesian VARFIMA approach. Applied Economics, 49, 1047-1054.

Bannigidadmath, D., \& Narayan, P. K. (2015). Stock return predictability and determinants of predictability and profits. Emerging Market Review, 153-173.

Baum, C. F., \& Caglayan, M. (2006). On the sensitivity of the volume and volatility of bilateral trade flows to exchange rate uncertainty. Journal of International Money E Finance, 29, 79-93.

Braun, M., \& Larrain, B. (2005). Finance and the business cycle: International, interindustry evidence. Journal of Finance, 60, 1097-1128.

Byrne, J. P., \& Davis, E. P. (2005). Investment and uncertainty in G7. Review of World Economics, 141, 1-32.

Campa, J. M. (1993). Entry by foreign firms in the United States under exchange rate uncertainty. Review of Economics and Statistics, 75, 614-622.

Chen, Y. C., \& Rogoff, K. (2003). Commodity currencies. Journal of International Economics, 60, 133-160.

Chen, Y. C., Rogoff, K., \& Rossi, B. (2010). Can exchange rates forecast commodity prices?. Quarterly Journal of Economics, 125, 1145-1194.

Colombo, V. (2013). Economic policy uncertainty in the US: Does it matter for the Euro area?. Economics Letters, 121, 39-42.

Dai, Y., Zhang, J., Yu, X., \& Li, X. (2017). Causality between economic policy uncertainty and exchange rate in China with considering quantile differences. Theoretical and Applied Economics, 24, 29-38.

Darby, J., Hallett, A. H., Ireland, J., \& Piscitelli, L. (1999). The impact of exchange rate uncertainty on the level of investment. Economic Journal, 109, C55-C67.

Devereux, M. B. (2004). Should the exchange rate be a shock absorber?. Journal of International Economics, 62, 359-377.

Devpura, N., Sharma, S., \& Narayan, P. K. (2017). Is stock return predictability time-varying?. Journal of International Financial Markets, Institutions and Money, DOI: https://doi.org/10.1016/j.intfin.2017.06.001

Engel, C., Mark, N., \& West, K. (2014). Factor model forecasts of exchange rates. Econometric Reviews, 34, 32-55.

Ferraro, D., Rogoff, K., \& Rossi, B. (2015). Can oil prices forecast exchange Rates? An empirical analysis of the relationship between commodity prices and exchange rates. Journal of International Money and Finance, 54, 116-141. 
Giacomini, R., \& Rossi, B. (2010). Forecast comparisons in unstable environments. Journal of Applied Economics, 25, 595-620.

Grier, R., \& Grier, K. B. (2006). On the real effects of inflation and inflation uncertainty in Mexico. Journal of Development Economics, 80, 478-500.

Han, L., Lv, Q., \& Yin, L. (2017). Can investor attention predict oil prices?. Energy Economics, 66, 547-558.

Jones, P. M., \& Olson, E. (2013). The time-varying correlation between uncertainty, output and inflation: Evidence from a DCC-GARCH model. Economic Letters, 118, 33-37.

Karnizova, L., \& Li, J. (2014). Economic policy uncertainty, financial markets and probability of US recessions. Economics Letters, 125, 261-265.

Krol, R. (2014). Economic policy uncertainty and exchange rate volatility. International Finance, 17, 241-256.

Lewellen, J. (2004). Predicting returns with financial ratios. Journal of Financial Economics, 74, 209-235.

Li, X., Balcilar, M., Gupta, R., \& Chang, T. (2016). The causal relationship between economic policy uncertainty and stock returns in China and India: Evidence from a bootstrap rolling window approach. Emerging Markets Finance and Trade, 52, 674-689.

Li, X., \& Peng, L. (2017). US economic policy uncertainty and co-movements between Chinese and US stock markets. Economic Modelling, 61, 27-39.

Meese, R. A., \& Rogoff, K. (1983). Empirical exchange rate models of the seventies: do they fit out of sample?. Journal of International Economics, 14, 3-24.

Molodtsova, T., Nikolsko-Rzhevskyy, A., \& Papell, D.H. (2011). Taylor rules and the euro. Journal of Money, Credit and Banking, 43, 535-552.

Narayan, P. K, Sharma, S., Poon, W., \& Westerlund, J. (2014). Do oil prices predict economic growth? New global evidence. Energy Economics, 41, 137-146.

Narayan, P. K., \& Bannigidadmath, D. (2015). Are Indian stock returns predictable?. Journal of Banking and Finance, 58, 506-531.

Narayan, P. K., \& Gupta, R. (2015). Has oil price predicted stock returns for over a century?. Energy Economics, 48, 18-23.

Narayan, P. K., Phan, D. H. B., Narayan, S., \& Bannigidadmath, D. (2017a). Is there a financial news risk premium in Islamic stocks?. Pacific-Basin Finance Journal, 42, 158-170.

Narayan, P. K., Phan, D. H. B., \& Sharma, S. (2017b). Are Islamic stock returns predictable? A global perspective. Pacific-Basin Finance Journal, 40A, 210-223.

Narayan, P. K., Phan, D. H. B., Thuraisamy, K. S., \& Westerlund, J. (2016). Price discovery and asset pricing. Pacific-Basin Finance Journal, 40A, 224-235.

Narayan, P. K., \& Sharma, S. (2015). Is carbon emissions trading profitable?. Economic Modelling, 47, 84-92.

Narayan, P. K., Sharma, S., \& Thuraisamy, K. S. (2015). Can governance quality predict stock market returns? New global evidence. Pacific-Basin Finance Journal, 35A, 367-380.

Obstfeld, M., \& Rogoff, K. S. (1998). Risks and exchange rates. NBER Working Paper Series 6694. National Bureau of Economic Research, Cambridge Massachusetts.

Phan, D. H. B., Sharma, S. S., \& Narayan, P. K. (2015). Stock return forecasting: some new evidence. International Review of Financial Analysis, 40, 38-51. 
Phan, DHB., Sharma, S., \& Tran, VT. (2018). can economic policy uncertainty predict stock returns? Global evidence. Journal of International Financial Markets, Institutions and Money, DOI: https://doi.org/10.1016/j.intfin.2018.04.004.

Record, N. (2003). Currency Overlay. The Wiley Finance Series, Wiley, United State.

Rossi, B., \& Inoue, A. (2012). Out-of-Sample forecast tests robust to the choice of window size. Journal of Business \& Economic Statistics, 30, 432-453.

Salisu, A., \& Isah, K. (2018). Predicting US inflation: Evidence from a new approach. Economic Modelling, 71, 134-158.

Servén, L. (2003). Real-exchange-rate uncertainty and private investment in LDCS. Review of Economics and Statistics, 85, 212-218.

Sharma, S. (2016). Can consumer price index predict gold price returns?. Economic Modelling, 55, 269-278.

Stambaugh, R. (1999). Predictive regressions. Journal of Financial Economics, 54,375421.

Stockhammar, P., \& Österholm, P. (2016). Effects of US policy uncertainty on Swedish GDP growth. Empirical Economics, 50, 443-462.

Urata, S., \& Kawai, H. (2000). The determinants of the location of foreign direct investment by Japanese small and medium-sized enterprises. Small Business Economics, 15, 79-103.

Wang, Y., Chen, C., \& Huang, Y. (2014). Economic policy uncertainty and corporate investment: Evidence from China. Pacific-Basin Finance Journal, 26, 227-243.

Westerlund, J., \& Narayan, P. (2012). Does the choice of estimator matter when forecasting stock returns. Journal of Banking and Finance, 36, 2632-2640.

Westerlund, J., \& Narayan, P. (2015). Testing for predictability in conditionally heteroskedastic stock returns. Journal of Financial Econometrics, 13, 342-375. 
This page is intentionally left blank 